\title{
LEGALITAS PERKAWINAN ADAT MENURUT UNDANG - UNDANG NO. 16 TAHUN 2019 TENTANG PERUBAHAN ATAS UNDANG-UNDANG NOMOR 1 TAHUN 1974 TENTANG PERKAWINAN
}

\author{
Ratna D.E. Sirait \\ Fakultas Hukum Universtas Katolik Santo Thomas, Medan, Indonesia \\ Email : ratnadesirait@gmail.com
}

\begin{abstract}
ABSTRAK
Indonesia adalah negara yang begitu kaya akan budaya dan tradisi,termasuk dalam ritual pernikahan atau perkawinan. Perkawinan merupakan moment spesial yang sangat dinantikan oleh pasangan. Apalagi ketika acara penuh makna ini berlangsung dengan lancar dan sesuai dengan konsep perkawinan yang diimpikan.Perkawinan adalah perilaku makluk ciptaan Tuhan Yang Maha Esa agar kehidupan di alam dunia berkembang biak. Pernikahan bukan saja terjadi di kalangan manusia, tetapi terjadi pada tumbuhan dan hewan. Karena manusia adalah makluk berakal, maka perkawinan merupakan salah satu bentuk budaya yang beraturan dengan tujuan memperoleh keturunan .Dalam masyarakat ada perkawinan yang dilaksanakan secara adat. Bentuk perkawinan secara adat ini adalah adalah suatu perkawinan adat yang dilaksanakan oleh kedua mempelai dengan tidak pemberkatan di gereja melainkan meminta kepada petinggi adat /tokoh adat. Perkawinan secara adat saja jelas bertentangan dengan UU No 16 Tahun 2019. Keabsahan perkawinan yang diatur dalam UU No.16 tahun 2019 yaitu dalam Pasal 2 ayat (1) menyatakan bahwa "perkawinan adalah sah apabila dilakukan menurut hukum masing-masing agama dan kepercayaannya itu'. Selanjutnya dalam Pasal 2 ayat (2) dinyatakan bahwa 'tiap-tiap perkawinan harus dicatatkan menurut peraturan perundang-undangan yang berlaku'. Perkawinan adat ini tidak memiliki akta perkawinannya. Akibatnya perkawinan ini tidak memiliki bukti sebagai perkawinan sah secara undang-undang.
\end{abstract}

\section{Kata Kunci : Legalitas, Perkawinan, Adat}

\section{ABSTRACT}

Indonesia is a country that rich of culture and traditions, including in marriage rituals. Marriage is a special moment that couples look forward to. Especially when this meaningful event takes place smoothly and in accordance with the concept of a dream of marriage. Marriage is the behavior of creatures created by God so that life in the natural world proliferates. Marriage does not only given to humans, but also plants and animals. Because humans are intelligent beings, marriage is a form of orderly culture with the aim of obtaining offspring. In society there are marriages carried out by custom. This traditional form of marriage is a customary marriage carried out by the bride and groom without a blessing at the church but asking traditional officials / traditional leaders. Customary marriage alone is clearly contrary to Law No. 16 of 2019. The legitimacy of marriage as regulated in Law No. 16 of 2019, namely in Article 2 paragraph (1) states that "marriage is legal if it is carried out according to the laws of each religion and belief. Furthermore, in Article 2 paragraph (2) it is stated that 'every marriage must be registered according to the applicable laws and regulations'. This customary marriage does not have a marriage certificate. As a result, this marriage has no proof as a legal marriage by law.

\section{Keyword: Legality, Marriage, Culture}




\section{A. PENDAHULUAN}

Indonesia adalah negara yang begitu kaya akan budaya dan tradisi, termasuk dalam ritual pernikahan atau perkawinan. Perkawinan merupakan moment spesial yang sangat dinantikan oleh pasangan. Apalagi ketika acara penuh makna ini berlangsung dengan lancar dan sesuai dengan konsep perkawinan yang diimpikan.

Perkawinan adalah perilaku makluk ciptaan Tuhan Yang Maha Esa agar kehidupan di alam dunia berkembang biak. ${ }^{1}$ Pernikahan bukan saja terjadi di kalangan manusia, tetapi terjadi pada tumbuhan dan hewan. Karena manusia adalah makluk berakal, maka perkawinan merupakan salah satu bentuk budaya yang beraturan dengan tujuan memperoleh keturunan.

Pada umumnya menurut hukum adat di Indonesia perkawinan itu bukan saja sebagai perikatan perdata, melainkan juga perikatan adat, sekaligus perikatan kekerabatan dan ketetanggaan, atau "dongan sahuta "(Batak).

Perkawinan adalah pertalian yang sah antara seorang lelaki dan seorang perempuan untuk waktu yang lama. ${ }^{3}$

Bagi sebagian masyarakat Indonesia, perkawinan adalah sebuah pranata yang tidak hanya mengikat seorang laki-laki dan seorang perempuan, tetapi juga mengikat sebuah keluarga besar yakni pihak keluarga laki-laki dan seorang perempuan ${ }^{4}$. Hal inilah yang mengakibatkan bahwa suatu perkawinan merupakan suatu hal yang sangat penting bagi kehidupan masyarakat .

Pandangan masyarakat tentang keabsahan perkawinan adalah melaksanakan upacara adat. Upacara adat ini adalah membayarkan adat kepada pihak perempuan bagi masyarakat yang sistim kemasyarakatannya patrinial, karena bentuk upacara adat dalam masyarakat ini adalah perkawinan jujur. Perkawinan jujur adalah perkawinan dengan pemberian pembayaran/pemberian jujur oleh pihak lak-laki kepada pihak perempuan. Maksud pembayaran atau pemberian jujur oleh pihak laki-laki kepada pihak perempuan adalah sebagai pertanda atau lambang diputuskannya hubungan kekeluargaan si Istri dengan orang tuanya, saudara-saudaranya dan bahkan masyarakatnya.

Defenisi perkawinan menurut pendapat para sarjana lebih luas dibandingkan dengan definisi perkawinan dalam Undang-Undang No.1 Tahun 1974 yang telah dirubah dengan Undang-Undang No.16 Tahun 2019 Tentang Perkawinan, dimana dalam Pasal 2 ayat (1) dikatakan, perkawinan sah apabila dilakukan menurut hukum masing-masing agamanya dan kepercayaannya itu. Hal itu berarti bahwa suatu perkawinan telah memenuhi syarat dan rukun nikah atau ijab kabul telah dilaksanakan (bagi muslim) dan pendeta/pastor telah melaksanakan pemberkatan nikah bagi no muslim. ${ }^{5}$

Dalam beberapa suku di Indonesia ada perkawinan yang dilaksanakan secara adat. Bentuk perkawinan secara adat ini adalah adalah suatu perkawinan adat yang dilaksanakan oleh kedua mempelai dengan tidak pemberkatan di gereja melainkan meminta kepada Tetuatetua/ Petinggi Adat.

Perkawinan secara adat saja jelas bertentangan dengan UU No 16 Tahun 2019. Dalam Pasal 2 ayat (2) dinyatakan bahwa "tiap-tiap perkawinan harus dicatatkan menurut peraturan per undang-undangan yang berlaku". Perkawinan adat ini tidak memiliki akta

\footnotetext{
${ }^{1}$ Hilman Hadikusuma, Hukum Perkawinan Indonesia menurut Perundangan, Hukum Adat dan Hukum Agama. Bandung: Mandar Maju. 2007.

${ }^{2}$ Djamanat Samosir, Legalasi Hak Ulayat Masyarakat Hukum Adat, Semarang: Universitas Diponegoro, 2013

${ }^{3}$ Subekti,Pokok-Pokok Hukum Perdata, Intermasa, Jakarta, 2008

${ }^{4}$ Septiani, Helga, Makna dan Fungsi Tradisi Sinamot dalam Adat Perkawinan Sukubangsa Batak Toba di

Perantauan Surabaya, 2011

${ }^{5}$ Syahuri, T, Legislasi hukum perkawinan di Indonesia: Pro-kontra pembentukannya hingga putusan Mahkamah Konstitusi, Kencana Prenada Media Group, 2013
}

Legalitas Perkawinan Adat menurut Undang-Undang No. 16 Tahun 2019 tentang Perubahan atas Undang-Undang Nomor 1 Tahun 1974 tentang Perkawinan. Oleh: Ratna 
perkawinannya. Akibatnya perkawinan ini tidak memiliki bukti sebagai perkawinan sah secara undang-undang.

Memahami dan mengerti tentang hukum adat adalah suatu kewajiban yang harus dilakukan apabila ingin melestarikan. Hukum adat yang ada pada sebagian masyarakat Indonesia merupakan satu kebudayaan yang patut dilestarikan. Salah satu unsur adat dalam kebudayaan adalah perkawinan.

Perkawinan adalah suatu cara untuk mengembangkan keturunan yang disepakati secara sah menurut ketentuan yang berlaku di masyarakat sebagai salah satu sarana melestarikan budaya. Adapun bentuk dan sistem perkawinan yang dianut oleh masyarakat adat dikenal banyak macam dan jenisnya. Perkawinan jika dititik beratkan pada cara melakukan perkawinan adat yang oleh para ahli hukum adat dibedakan dalam 3 cara, yaitu:
a. Kawin Pinang (Aanzoekhuwelijk)
b. Kawin Lari bersama (Wegloophuwelijk)
c. Kawin lari dengan paksaan (Schaakhuwelijk)

Sebelum Tahun 1974 di Indonesia telah terjadi pluralisme dalam hukum perkawinan yang antara lain:

a. Bagi orang yang beragama islam berlaku hukum islam yang telah diresepsi dalam hukum adat

b. Bagi orang Indonesia asli lainnya berlaku hukum adat

c. Bagi orang Indonesia Asli beragama kristen berlaku Ordonansi Perkawinan Indonesia Kristen

d. Bagi orang Timur Asing lainnya dan Warga Negara Indanesia keturunan Timur Asing lainnya berlaku Hukum Adat mereka.

e. Bagi orang Eropa dan Warga Negara Indonesia Keturunan Eropa dan yang disamakan dengan mereka berlaku Kitab Undang-Undang Hukum Perdata.

Undang-Undang No 16 Tahun 2019 dalam Pasal 1 mendefinisikan perkawinan "ikatan lahir batin antar seorang pria dengan seorang wanita sebagai suami istri dengan tujuan membentuk keluarga (rumah tangga) yang bahagia dan kekal berdasarkan KeTuhanan yang Maha Esa". berikut:

Ketentuan Pasal 1 undang-undang ini dapat dirinci dalam beberapa unsur, sebagai

a. Adanya ikatan lahir batin. Perkawinan dikatakan sebagai suatu persetujuan yang menimbulkan ikatan lahiriah maupun bathiniah antar seorang pria dan wanita.

b. Adanya seorang pria dan wanita. Unsur pria dan wanita menunjukkan bahwa orang yang akan melangsungkan perkawinan harus berbeda jenis kelamin. Hal ini dimaksud untuk memiiki keturunan.

c. Adanya tujuan

Tujuan perkawinan adalah membentuk keluarga (rumah tangga) yang bahagia dan kekal. Pada hakekatnya, perkawinan tidak bersifat sementara.

d. Berdasarkan KeTuhanan Yang Maha Esa.

Perkawinan tidak semata-mata persoalan keperdataan, tetapi juga persoalan agama. Peran agama sangat penting karena perkawinan dikatakan sah apabila dilaksanakan menurut agama. Oleh sebab itu, perkawinan harus memperhatikan unsur agama.

Menurut KUH Perdata perkawinan dipandang sebagai suatu hubungan hukum di bidang hukum keluarga, sama seperti hubungan-hubungan hukum lainnya, yang harus dilakukan sesuai dengan hukum negara. Selain sebuah hubungan hukum biasa yang sama seperti hubungan hukum lainnya, KUH Perdata melepaskan aspek-aspek lain selain dari aspek huum negara dari perkawinan itu. 
Ketentuan ini berbeda dengan ketentuan dalam Undang-Undang No 16 Tahun 2019, perkawinan didasarkan pada kepercayaan kepada Tuhan Yang maha Esa, yang berarti sesgala sesuatu yang berhubungan dengan pelaksanaan perkawinan dan kehidupan perkawinan itu sendiri, hendaknya senantiasa berlangsung dalam keyakinan kepada Tuhan.

Syarat sahnya suatu perkawinan dalam Undang-Undang No 16 tahun 2019 dibagi menjadi dua, yaitu syarat materil dan syarat formil.

1. Syarat Materil

Syarat materil adalah syarat yang melekat dari pihak yang melaksanakan perkawinan, dansyarat ini bersifat mutlak dan harus dipenuhi oleh pihak tersebut. Syarat materil ini tercantum dalam Pasal 6 sampai pasal 11 Undang-Undang No.16 Tahun 2019. Adapun syarat materil ini adalah sebagai berkut:

1) Persetujuan kedua calon mempelai

2) Jika belum berusia 21 Tahun wajib mendapat ijin dari kedua orang tua

3) Ketentuan umur pria dan wanita berumur 19 tahun

4) Tidak terikat dalam suatu perkawinan

5) Tidak melakukan perkawinan atau perceraian untuk kedua kalinya

6) Ketentuan bagi wanita yang sudah pernah menikah sebelumnya. Ketentuan bagi wanita yang sudah pernah menikah sebelumnya.

2. Syarat Formal

Syarat formal adalah syarat yang menyangkut tata cara atau prosedur pelaksanaan pekawinan. Syarat ini juga mengatur proses pencatatan perkawinan oleh dinas kependudukan dan catatan sipil. Syarat formal ini dimuat dalam Peraturan Pemerintah No 9 Tahun 1975 Pasal 3,4,5,6,7,8 dan 9.

Kebasahan perkawinan diatur dalam Pasal 2 ayat (1) Undang-Undang No.16 Tahun 2019 yang menyatakan bahwa " perkawinan adalah sah apabila dilakukan menurut hukum masing-masing agamanya dan kepercayaannnya itu". Oleh sebab itu, perkawinan sah menurut hukum perkawinan nasional adalah perkawinan yang dilaksanakan menurut tata tertib aturan hukum yang berlaku dalam agama islam, kristen, katolik, hindu, budha dan konghucu. Hukum masing-masing agamanya adalah hukum dari salah satu agama yang dianut oleh kedua mempelai atau keluarganya.

Menurut pasal 2 ayat (1) Undang-Undang No.16 Tahun 2019 yang menyatakan bahwa keabsahan perkawinan pada hukum agama. Hukum agama menentukan sah tidaknya suatu perkawinan. Oleh sebab itu hukum agama merupakan syarat mutlak perkawinan yang sah.

Keabsahan perkawinan juga ditaur dalam Pasal 2 ayat (2) Undang-Undang No.16 Tahun 2019 yang menyatakan bahwa :'Tiap-tiap perkawinan dicatat menurut peraturan perundang-undangan yang berlaku. " Pasal ini menegaskan bahwa perkawinan yang tidak sah tidak cukup ditinjau dari unsur agamanya saja, melainkan juga peraturan perundangundangan yang berlaku. Pencatatan perkawinan dibagi menjadi dua, yaitu:

1. Pencatatan perkawinan bagi yang beragama Islam diatur dalam Undang-Undang No.32

Tahun 1954 Tentang Pencatatan Nikah, Talak dan Rujuk. Pencatatan perkawinan dilakukan di Kantor Urusan Agama (KUA)

2. Pencatatan perkawinan bagi non Islam diatur dalam Peraturan Pemerintah No 9 Tahun 1975. Pencatatan perkawinan ini dilakukan di Kantor Dinas Kependudukan dan Catatan Sipil (DUKCAPIL).

Pencatatan perkawinan ini dituangkan dalam bentuk akta otentik berupa akta perkawinan. Akta otentik merujuk kepada Pasal 1868 KUH Perdata yang menyebutkan bahwa akta otentik adalah akta yang dibuat dihadapan pegawai- pegawai umum yang 
berkuasa ditempat mana akta dibuat. Ketentuan tersebut menjelaskan empat (4) unsur yang harus ada dalam pembuatan otentik, yaitu:

a. Berbentuk tulisan yang dibuat untuk memenuhi suatu bukti perbuatan hukum.

b. Dibuat dalam bentuk yang ditentukan undang-undang. Hal ini menyatakan kepada format dari akta otentik itu sendiri, apakah sudah sesuai dengan format yang ditentukan oleh undang-undang terkait atau belum (Pasal 12 Peraturan Pemerintah No.9 Tahun 1975).

c. Dibuat oleh pegawai umum yang berkuasa. Akta yang bersifat otentik tersebut harus dibuat oleh pejabat umum yang berwenang melakukan pencatatan sesuai dengan tempat dimana akta dibuat. Oleh sebab itu, syarat sahnya suatu perkawinan ditinjau dari pandangan Undang-Undang No.16 Tahun 2019 adalah harus dilaksanakan sesuai dengan agama dan kepercayaan masing-masing (Pasal 2 ayat (1) Undang-Undang No.16 Tahun 2019) dan harus dicatatkan ke instansi yang ditunjuk secara sah oleh peraturan perundang- undangan (Pasal 2 ayat (1) dan (2) PP No.9 Tahun 1975).

\section{B. PEMBAHASAN}

\section{Sistem dan Pelaksanaan Dalam Perkawinan Adat}

Dikalangan masyarakat adat sendiri, istilah hukum adat tidak banyak dikenal, yang biasa disebut anggota masyarakat ialah "adat" saja, dalam arti "kebiasaan" untuk dibedakan dengan istilah "hukum" dalam arti peraturan agama. Dengan demikian yang dimaksud hukum adat perkawinan adalah hukum masyarakat (hukum rakyat) yang tidak tertulis dalam perundang-undangan negara yang mengatur tata tertib perkawinan, jika terjadi pelanggaran terhadap hukum perundang-undangan maka yang mengadili adalah Pengadilan Agama atau Pengadilan Negeri, sedangkan jika terjadi pelangaran hukum adat, maka yang mengadili dalam arti menyelesaikan adalah Pengadilan Adat (peradilan masyarakat keluarga atau kerabat) yang bersangkutan.

Berlakunya hukum adat perkawinan, tergantung pada pola susunan masyarakat adat. Oleh karenanya tanpa mengetahui bagaimana susunan masyarakat adat bersangkutan, maka tidak mudah dapat diketahui hukum perkawinannya. Di dalam masyarakat adat di berbagai daerah, berlaku sistem kekerabatan yang berbeda-beda, sehingga sistem pelaksanaan perkawinan adat yang berlangsung antara satu dan yang lain mempunyai hak dan kewajiban yang berbedabeda pula.

Sistem dan pelaksanaan perkawinan adat menurut sistem perkawinan yang berlaku dalam hukum adat Indonesia dibedakan atas 3 macam, yaitu:

a) Sistem endogami, yaitu perkawinan yang diperbolehkan hanya dari suku sendiri seagama, desa, dan lapisan masyarakat. Sistem perkawinan ini terdapat di masyarakat Toraja dan Flores Nusa Tenggara Timur. Pada waktu yang lampau, masyarakat Ngadhubhaga Flores Nusa Tenggara Timur menggunakan sistem endogami, dimana gadis yang berasal dari kalangan bangsawan (gae meze) dilarang kawin dengan yang tidak berasal dari kalangan bangsawan.

b) Sistem eksogami, yaitu perkawinan dengan orang di luar suku keluarganya atau di luar marganya (eksogami desa, klan/marga). Sistem perkawinan ini terdapat di Alas, Tapanuli, Minangkabau, Sumatera Selatan, Buru, dan Seram.

c) Sistem perkawinan eleutrogami, yaitu sistem perkawinan yang tidak mengenal larangan atau keharusan-keharusan seperti dalam sistem endogami dan eksogami. Sistem ini umumnya digunakan oleh masyarakat jawa dan sunda.

\section{Kaitan Antara Undang-Undang No.16 Tahun 2019 Dengan Hukum Adat}




\section{a. Asas dalam perkawinan}

Pasal 3 ayat (1) Undang-Undang No.16 Tahun 2019 menegaskan "Pada asasnya dalam suatu perkawinan seorang pria hanya boleh mempunyai seorang isteri. Seorang wanita hanya boleh mempunyai seorang suami". Dalam Pasal tersebut menegaskan bahwa terdapat asas monogami dalam perkawinan nasional, yaitu suatu asas yang menghendaki bahwa dalam waktu yang sama seorang laki-laki hanya boleh mempunyai seorang isteri dan sebaliknya seorang isteri hanya boleh mempunyai seorang suami. Pasal $27 \mathrm{KUH}$ Perdata dengan tegas menyebutkan asas ini, Oleh karena itu, Undang-Undang No.16 Tahun 2019 memiliki tujuan yang sama dengan hukum adat.

\section{b. Syarat sah perkawinan}

Syarat sah melaksanakan perkawinan berdasarkan Undang-Undang No.16 Tahun 2019 adalah sebagai berikut:

1. Kesediaan calon mempelai perempuan untuk dipinang oleh calon mempelai laki-laki. Menurut Undang-Undang No.16 Tahun 2019 diatur di dalam Pasal 6 ayat (1), ketersediaan calon mempelai harus ditanyakan terlebih dahulu sebelum dilaksanakan perkawinan.

2. Kedua mempelai tidak sedang terikat di dalam suatu perkawinan. Menurut UndangUndang No.16 Tahun 2019 menganut asas monogami. Artinya seorang pria hanya boleh memiliki seorang isteri. Hal ini jelas tertuang di dalam Pasal 3 ayat (1) bahwa, "Pada asasnya seorang pria hanya boleh memiliki seorang isteri dan seorang wanita hanya boleh memiliki seorang suami".

3. Izin pelaksanaan perkawinan. Menurut Undang-Undang No.16 Tahun 2019 mengatur dengan tegas salah satu syarat perkawinan dilihat dari segi umur. Hal ini diatur dalam Pasal 6 ayat (2) menegaskan, "untuk melangsungkan suatu perkawinan seseorang yang belum mencapai umur 21 (dua puluh satu) Tahun harus mendapat izin kedua orangtuanya".

\section{c. Hak Dan Kewajiban Orang Tua Terhadap Anak}

Kaitan berikutnya terdapat pada hak dan kewajiban orangtua dan anak. Munculnya berbagai permasalahan sosial yang terjadi pada saat ini salah satu penyebabnya adalah akibat merenggang dan hancurnya sistem dalam keluarga baik sistem nilai maupun sistem aturan hak dan kewajiban sehingga saat ini orang tua kurang memahami apa yang menjadi hak dan kewajibannya terhadap Anak.

Begitu juga sebaliknya, orang tua kurang memahami apa yang menjadi hak dan kewajiban terhadap anak mereka. Mengetahui hak dan kewajiban di dalam keluarga merupakan bagian dari realisasi keimanan dan adab kita sebagai seorang muslim. Perhatian yang besar ini merupakan aplikasi dari nilai-nilai Islam yang telah kita serap dan kita pahami bersama. Dengan mengetahui tugas dan tanggung jawab masing-masing di dalam rumah, pertikaian dan ketidak harmonisan akan hilang dengan sendirinya.

Oleh karena itu, anak membutuhkan bantuan, bimbingan dan pengarahan dari orang tua. Awal mula manusia berinteraksi dan bersosialisasi adalah dari rumah.

Dalam Pasal 45 ayat (1) Undang-Undang No.16 Tahun 2019 menyebutkan bahwa "kedua orangtua wajib memelihara dan mendidik anak-anak mereka sebaik-baiknya". Hal ini menunjukkan keberadaan anak adalah suatu hal yang sangat penting dalam keluarga, tanpa kehadiran anak maka rumah tangga belum dapat dikatakan sebagai suatu keluarga yang lengkap.

Pada Pasal 46 “Anak wajib menghormati orang tua dan mentaati kehendak mereka yang baik. Jika anak telah dewasa, ia wajib memelihara menurut kemampuannya, orang tua dan keluarga dalam garis lurus keatas, bila mereka itu memerlukan bantuannya." 
Pasal 47 "Anak yang belum mencapai umur 18 (delapan belas) Tahun atau belum pernah melangsungkan perkawinan ada di bawah kekuasaan orang tuanya selama mereka tidak dicabut dari kekuasaannya. Orang tua mewakili anak tersebut mengenai segala perbuatan hukum di dalam dan diluar Pengadilan".

Pasal 48 "Orang tua tidak diperbolehkan memindahkan hak atau menggadaikan barang- barang tetap yang dimiliki anaknya yang belum berumur 18 (delapan belas) Tahun atau belum pernah melangsungkan perkawinan, kecuali apabila kepentingan anak itu menghendakinya".

Di dalam Pasal 49 dijelaskan bahwa "Salah seorang atau kedua orang tua dapat dicabut kekuasannya terhadap seorang anak atau lebih untuk waktu yang tertentu atas permintaan orang tua yang lain, keluarga anak dalam garis lurus keatas dan saudara kandung yang telah dewasa atau pejabat yang berwenang, dengan keputusan Pengadilan dalam halhal:la sangat melalaikan kewajibannya terhadap anaknya dan la berkelakuan buruk sekali. Meskipun orang tua dicabut kekuasaannya, mereka masih tetap berkewajiban untuk memberi biaya pemeliharaan kepada anak tersebut".

Dalam Pasal 49 di atas dijelaskan bahwa kekuasaan orang tua adalah kekuasaan, kewajiban-kewajiban terhadap anak mereka yang sah yang masih di bawah umur sampai anak tersebut dewasa dan juga sampai anak tersebut melangsungkan perkawinan. Kekuasaan dan kewajiban menyangkut tentang diri pribadi ataupun mengenai harta kekayaan selama perkawinan berlangsung. Di dalam menjalankan kewajiban, jika orang tua tersebut menjalankan tugasnya tidak secara wajar dan tidak sebagaimana mestinya, maka orang tua tersebut dapat dibebaskan dari kekuasaan orang tua demi untuk kepentingan anak-anak.

Untuk memperoleh kehidupan rumah tangga yang penuh rasa kasih dan sayang serta berlangsungnya kehidupan rumah tangga, dalam keluarga itu harus ada yang bertanggung jawab. Bertanggung jawab secara materiil maupun spiritual. Dalam hal ini kewajiban tersebut dibebankan kepada orang tua. Orang tua berkewajiban memenuhi keperluan anakanak, baik materiil maupun spirituil, demi tegaknya rumah tangga yang tenteram. Namun demikian, bagaimana jika anak-anak yang menjadi tanggung jawab orang tua itu mampu memenuhi keperluannya sendiri atau bahkan lebih dari itu. Apakah tanggung jawab keluarga itu hanya dibebankan kepada orang tua saja mutlak tanpa adanya unsur pertolongan seperti pemanfaatan hak milik anggota keluarga yang lain seperti anak. Kemudian yang namanya orang tua itu tidak selamanya dalam keadaan (kaya) akan tetapi sebagaimana manusia umumnya ia kadang-kadang menemui suatu kesulitan. Maka timbul masalah, apakah tanggung jawab kehidupan keluarga itu secara mutlak menjadi tanggung jawab orang tua dengan tanpa adanya kebolehan memanfaatkan hak milik anak untuk kepentingan orang tua. ${ }^{6}$

Apabila suatu perkawinan memperoleh keturunan, maka perkawinan tersebut tidak hanya menimbulkan hak dan kewajiban antara suami dan istri yang bersangkutan, akan tetapi juga menimbulkan hak dan kewajiban antara suami istri sebagai orang tua dan anak-anaknya. Hak dan kewajiban antara orang tua dan anak-anak ini dalam Undang-Undang No.16 Tahun 2019 diatur dalam pasal 45-49. Dalam Pasal 45 ditentukan bahwa kedua orang tua wajib memelihara dan mendidik anak mereka dengan sebaik-baiknya, sampai anak itu kawin atau dapat berdiri sendiri. Kewajiban ini berlaku terus meskipun perkawinan antara kedua orang tua itu putus.

Disamping kewajiban untuk memelihara dan mendidik tersebut, orang tua juga menguasai anaknya yang belum mencapai umur 18 Tahun atau belum pemah melangsungkan perkawinan. Kekuasaan orang tua ini meliputi juga untuk mewakili anak yang belum dewasa ini dalam melakukan perbuatan hukum di dalam dan diluar pengadilan (Pasal 47). Meskipun

\footnotetext{
${ }^{6}$ Al Barry, Zakariya Ahmad. Hukum Anak-anak Dalam Islam. Penerjemah Chadijah Nasution. Jakarta: Bulan
} Bintang, 1977. 
demikian kekuasaan orang tua ada batasnya yaitu tidak boleh memindahkan hak atau menggadaikan barang-barang tetap milik anaknya yang belum berumur 18 Tahun atau belum pernah melangsungkan perkawinan. Kecuali apabila kepentingan anak itu menghendakinya (Pasal 48). Kekuasaan salah seorang atau kedua orang tua terhadap anaknya dapat dicabut untuk waktu tertentu, apabila ia sangat melalaikan kewajibannya terhadap anaknya atau berkelakuan buruk sekali. ${ }^{7}$

Pencabutan kekuasaan orang tua terhadap seorang anaknya ini dilakukan dengan keputusan pengadilan atas permintaan orang tua yanglain keluarga dalam garis turun keatas dan saudara kandung yang telah dewasa atau penjabat yang berwenang. Kekuasaan orang tua yang dicabut ini tidak termasuk kekuasaan sebagai wali nikah. Meskipun orang tua dicabut kekuasaannya, namun mereka masih tetap kewajiban untuk memberi biaya pemeliharaan anaknya tersebut (pasal 49).

Sebaliknya, anak tidak hanya mempunyai hak terhadap orang tuanya, akan tetapi juga mempunyai kewajiban. Kewajiban anak yang utama terhadap orang tuanya adalah menghormati dan mentaati kehendak yang baik dari orang tuanya. Dan bila mana anak telah dewasa ia wajib memelihara orang tuanya dengan sebaik-baiknya menurut kemampuannya. Bahkan anak juga berkewajiban untuk memelihara keluarga dalam garis lurus keatas, bila mereka ini memerlukan bantuannya (Pasal 46). ${ }^{8}$

\section{Penyebab Masyarakat Melaksanakan Perkawinan Adat}

Perkawinan merupakan hal penting dalam kehidupan umat manusia. Karena dengan perkawinan kehidupan rumah tangga dapat ditegakkan dan dibina sesuai dengan norma yang berlaku serta tata kelakuan/adat istiadat masyarakat setempat. Membangun rumah tangga tidak terlepas dari peran dua insan yang berlainan jenis (suami-istri) di dalamnya, mereka saling berhubungan agar mendapat keturunan sebagai penerus generasi masa depan. Perkawinan juga merupakan peristiwa penting yang berada diantara tengah-tengah peristiwa "kelahiran" dan "kematian". Oleh karena itu, segala hal yang berkaitan dengan masalah perkawinan sangat diperhatikan demi menjaga sakralitas dari perkawinan itu sendiri.

Indonesia adalah Negara kepulauan yang terletak pada garis katulistiwa. Penduduk yang berdiam berasal dari pulau-pulau di dalamnya, bermacam ragam adat budaya dan hukum adatnya masih terasa kental, hal ini sesuai dengan semboyan Negara Indonesia "Bhineka Tunggal Ika" yang berarti meskipun terdapat perbedaan suku, adat, bahasa, ras, agama, budaya dan lain-lain tetapi tetap satu kesatuan.

Masyarakat berbagai budaya meyakini perkawinan sebagai masa peralihan dari tingkat kehidupan remaja ke tingkat kehidupan berkeluarga. Kebudayaan sebagai produk kerja manusia mengalami pergeseran karena sistem nilai-sistem nilai yang berlaku dalam masyarakat bergeser sedikit demi sedikit digantikan oleh sistem nilai baru. Unsur-unsur pokok kebudayaan adalah:

a) Peralatan dan perlengkapan hidup manusia (pakaian, perumahan, alat-lat rumah tangga, senjata, alat-alat produksi, transport dan sebagainya).

b) Mata pencaharian hidup dan sistem-sistem ekonomi (pertanian, peternakan, sistem produksi, sistem distribusi dan sebagainya).

c) Sistem kemasyarakatan (sistem kekerabatan, organisasi politik, sistem hukum, sistem perkawinan).

d) Bahasa (lisan maupun tertulis).

e) Kesenian (seni rupa, seni suara, seni gerak, dan sebagainya).

f) Sistem pengetahuan.

\footnotetext{
${ }^{7}$ Prawirohmijoyo Soetojo R., dan Safioedin Azis, Hukum orang dan Keluarga, 1986
}

${ }^{8}$ H.F.A., Vollmar, Hukum Keluarga Menurut KUH Perdata, 1981 
g) Religi (sistem kepercayaan).

Sebagaimana tata tertib adat perkawinan antara masyarakat adat yang satu berbeda dengan masyarakat adat yang lain, antara suku bangsa yang satu berbeda dengan suku bangsa yang lain, antara yang beragama Islam berbeda dengan yang beragama Hindu, Kristen, Budha dan lain-lain. Suku adalah kelompok sosial dalam sistem sosial atau kebudayaan yang mempunyai arti atau kedudukan tertentu karena keturunan, adat, agama, dan bahasa. Dari setiap suku dari daerah memiliki suku yang berbeda dan setiap suku memiliki budaya yang berbeda pula tergantung pada lingkungan. berikut:

Beberapa faktor penyebab melaksanakan perkawinan secara adat adalah sebagai

a) Penceraian Hidup

b) Hubungan Yang Tidak Direstui Kedua Orangtua

c) Pergaulan Bebas

d) Perkawinan Beda Agama Dan Kepercayaan

e) Faktor Ekonomi

\section{Legalitas Perkawinan Secara Adat}

Ada beberapa suku atau kelompok masyarakat yang menutup diri dengan perubahan zaman dengan tetap mempertahankan nilai-nilai adat yang hidup pada kelompok mereka sendiri karena sebuah perubahan memiliki akibat terhadap hilangnya nilai-nilai (adat) luhur yang telah mereka anut secara turun-temurun dari nenek moyangnya, yang mana seharusnya tidak ada hukum yang lebih tinggi dari hukum negara. Negara memiliki peran menciptakan hukum, jadi segala sesuatu harus tunduk kepadanya. negara di sini dianggap sebagai suatu keutuhan yang menciptakan peraturan-peraturan hukum.

Bagi Indonesia adalah mutlak adanya Undang-Undang Perkawinan Nasional yang menampung prinsip-prinsip serta memberikan landasan hukum perkawinan yang selama ini menjadi pegangan dan telah berlaku bagi berbagai golongan dalam masyarakat kita yang mana sesuai dengan landasan falsafah Pancasila dan Undang-Undang Dasar 1945, maka undang-undang ini disatu pihak harus dapat mewujudkan prinsip-prinsip yang terkandung dalam Pancasila dan Undang-Undang Dasar 1945, sedangkan di lain pihak harus dapat pula menampung segala kenyataan yang hidup dalam masyarakat.

Seorang laki-laki dan seorang wanita yang dulunya merupakan pribadi yang bebas tanpa ikatan hukum, setelah perkawinan menjadi terikat lahir dan batin sebagai suami istri. Perkawinan adalah sah, apabila dilakukan menurut hukum masing-masing agamanya dan kepercayaannya itu.

Hukum adat menunjukkan sikap yang dinamis sehingga dapat berkembang menyesuaikan diri dengan perkembangan jaman karena mempunyai nilai-nilai universal maupun lembaga-lembaga hukum yang dalam bentuk pernyataan modern. Hal ini berarti pula hukum baru (hukum asing, hukum barat) sepanjang untuk memperkaya dan mengembangkan hukum nasional, asal tidak bertentangan dengan Pancasila dan UndangUndang Dasar 1945.

Perkawinan yang dilakukan dengan dasar pijak norma-norma hukum adat tentu tidak bisa dipandang sebagai sebuah pelanggaran aturan menurut hukum nasional karena perkawinan adalah sah, apabila dilakukan menurut hukum agama dan kepercayaannya akan tetapi pada suatu cara pandang tertentu perkawinan hanya dipandang sah hanya menurut agama dan kepercayaannya saja akan tetapi pada sisi lain dalam hal ini pemerintah memiliki aturan-aturan lain yang wajib diikuti baik mengenai syara $t$ tentang pencatatan terhadap perkawinan tersebut yaitu pada Pasal 2 ayat (2) Undang-Undang Nomor 16 Tahun 2019 Tentang Perkawinan dan syarat tentang batas umur untuk dapat melaksanakan perkawinan 
yakni pada Pasal 7 ayat (1) yaitu "Perkawinan hanya diizinkan jika pihak pria dan wanita sudah mencapai umur 19 tahun', karena maksud dari syarat ini adalah telah mencapai usia dewasa dalam melakukan perbuatan hukum. Terdapat kesamaan maksud dan tujuan dari peraturan perundang-undangan tersebut, bahwa keabsahan yang hakiki mengenai syarat sah dari peristiwa hukum berkenaan perkawinan yang dilakukan di Negara Republik Indonesia tidak cukup hanya menjalankan hukum adat saja melainkan harus mentaati aturan hukum positif yang berlaku di Indonesia.

Dewasa ini, peraturan per undang-undangan lain yang beirisan langsung dengan perlindungan anak termaktub dalam Undang-Undang Nomor 35 Tahun 2014 Tentang Perubahan atas Undang-Undang Nomor 23 Tahun 2002 Tentang Perlindungan Anak, yang dimaksud dengan anak sebagaimana pada Pasal 1 Angka 1 pada undang-undang tersebut di atas mengatakan bahwa anak adalah seseorang yang belum berusia 18 (delapan belas) tahun, termasuk anak yang masih dalam kandungan. Maka dari pada itu untuk usia di bawah angka tersebut di atas dipandang oleh negara sebagai individu yang belum dewasa dan negara serta pemerintah memiliki kewajiban untuk melindunginya, hal ini jelas termaktub pada Pasal 22 dan Pasal 23 ayat (1) dan ayat (2) yang menjabarkan bahwa negara dan pemerintah berkewajiban dan bertanggung jawab memberikan dukungan sarana dan prasarana dalam penyelenggaraan perlindungan anak serta negara dan pemerintah dapat memberikan jaminan perlindungan, pemeliharaan, dan kesejahteraan anak dengan memperhatikan hak dan kewajiban orang tua, wali, atau orang lain yang secara hukum bertanggung jawab terhadap anak dan mengawasi penyelenggaraan perlindungan anak itu sendiri.

Terkait dengan masalah perkawinan, maka budaya dan aturan yang berlaku pada suatu masyarakat tidak terlepas dari pengaruh budaya dan lingkungan masyarakat itu berada. Begitu juga pergaulan masyarakat setempat terbentuk karena dipengaruhi oleh kebiasaan, kepercayaan dan keagamaan yang dianut masyarakat tersebut.

Perkawinan yang sah adalah perkawinan yang berdasarkan hukum agama (Pasal 2 ayat (1) Undang-Undang No.16 Tahun 2016) Oleh sebab itu, perkawinan secara adat adalah perkawinan yang tidak sah. Perkawinan yang dilaksanakan secara adat akan berdampak terhadap anak yang dilahirkan. Beberapa dampak perkawinan secara adat terhadap anak adalah sebagai berikut:

a) Anak yang dilahirkan hanya memiliki hubungan perdata dengan ibunya sedangkan kepada ayah biologisnya tidak (Pasal 43 ayat (1) Undang-Undang No.16 Tahun 2019)

b) Anak tidak berhak mendapatkan nafkah dan warisan

c) Anak akan mengalami hambatan dalam proses pengurusan akta perkawinan.

Proses legalitas dari perkawinan secara adat juga harus sesuai dengan Peraturan Pemerintah No.9 Tahun 1975 tentang pelaksanaan Undang-Undang No.1 Tahun 1974 yang telah diubah dengan Undang-Undang No. 16 Tahun 2019 yang menyatakan dalam setiap perkawinan harus dibutuhkan pencatatan dalam akta perkawinan. Akta perkawinan ini sebagai bukti bahwa perkawinan ini telah sah dilaksanakan secara agama dan kepercayaan.

Dalam proses melegalkan perkawinan secara adat ada syarat syarat yang harus dipenuhi, mulai dari biaya yang cukup besar sampai dengan pemenuhan syarat yang cukup rumit, sehingga dalam pelaksanaanya ada hambatan-hambatan yang harus dihadapi oleh para pihak.

\section{KESIMPULAN}

Keberadaan hukum adat sangat kuat pengaruhnya terhadap kehidupan masyarakat jika dibandingkan dengan hukum positif yang berlaku di Indonesia, khususnya tentang hukum perkawinan. Namun sebagai bagian dari Warga Negara Indonesia tetap harus mengikuti peraturan perundang-undangan yang berlaku. Aturan-aturan berkenaan dengan syarat-syarat 
sahnya perkawinan menurut negara mengenai perkawinan, aturan-aturan mengenai syarat sahnya suatu perkawinan wajib ditegakkan dan dijalankan oleh seluruh Warga Negara Indonesia tanpa terkecuali.

Legalitas perkawinan yang hanya dilaksanakan secara adat dmenurut Undang-Undang No 16 Tahun 2019 adalah tidak sah, hal ini sesuai dengan Pasal 2 ayat (1), dimana perkawinan adalah sah apabila dilakukan menurut hukum masing-masing agamanya dan kepercayaannya itu. Selanjutnya dalam ayat (2) dinyatakan bahwawa, "Tiap-tiap perkawinan harus dicatatkan menurut peraturan perundang-undangan yang berlaku". Perkawinan adat tidak memiliki akta perkawinan, akibatnya perkawinan itu tidak memiliki bukti sebagai perkawinan yang sah secara undang-undang.

\section{DAFTAR PUSTAKA}

Al Barry, Zakariya Ahmad. Hukum Anak-anak Dalam Islam. Penerjemah Chadijah Nasution. Jakarta: Bulan Bintang, 1977.

Asmin, 1986, Status Perkawinan Antara Agama Ditinjau Dari Undang-undang Nomor 1 Tahun 1974, PT. Dian Rakyat, Jakarta.

Hadikusuma, H., 1990, Hukum Perkawinan Indonesia, Mandar Maju, Bandung .

Harahap, M Yahya, 1993. Hukum Perkawinan di Indonesia, Zahir Trad Co, Medan.

Hilman Hadikusuma, Hukum Perkawinan Indonesia menurut Perundangan, Hukum Adat dan Hukum Agama. Bandung: Mandar Maju. 2007.

Manik, H,S., 2012, Makna dan Fungsi Tradisi Sinamot Dalam Adat perkawinan Suku bangsa Batak Toba di Perantauan Surabaya, Bio Kultur, Surabaya.

Moleong Lexy J. 2004, Metodologi Penelitian Kualitatif, Bandung: Remaja Rosdakarya

Muhammad, Bushar, SH, Prof, 2006, Pokok-Pokok Hukum Adat, Pradnya Paramita, Jakarta

Pustaka Yustisia, Perundangan Tentang Anak. Yogyakarta: Pustaka Yustisia, 2010.

Prawirohmijoyo Soetojo R., dan Safioedin Azis, Hukum orang dan Keluarga, 1986

Samosir, Djamanat; Legalasi Hak Ulayat Masyarakat Hukum Adat, Semarang: Universitas Diponegoro, 2013

Samosir, Dj., 2013, Hukum Adat Indonesia, Eksistensi Dalam Dinamika Perkembangan Hukum di Indonesia, Aulia, Bandung

Septiani, Helga, Makna dan Fungsi Tradisi Sinamot dalam Adat Perkawinan Sukubangsa Batak Toba di Perantauan Surabaya, 2011

Sidabalok, J., Ratna, D.E., 2017, HUKUM PERDATA Menurut KUHPerda dan Pekembangannya di Dalam Perundang-Undangan Indonesia, USU Press, Medan

Sudarsono, Drs. Sh. M.Si, 2005. Hukum Perkawinan Nasional, Renika Cipta, Jakarta.

Sudarsono, Hukum Kekeluargaan Nasional, Jakarta: Renika Cipta, 1991

Sumiyati, 1982, Hukum Perkawinan dan Undang-Undang Perkawinan, Liberty, Yogyakarta.

Sosroatmodjo, Arso, H, SH, dan Aulawi, Wasit, MA. H.A, 1975. Hukum Perkawinan di Indonesia, Alumni, Bandung.

Subekti, 1984, Pokok-Pokok Hukum Perdata, Intermasa, Jakarta.

Sudarsono, Drs. Sh. M.Si, 2005. Hukum Perkawinan Nasional, Renika Cipta, Jakarta.

Sumiyati, 1982, Hukum Perkawinan dan Undang-Undang Perkawinan, Liberty, Yogyakarta.

Syahuri, T, 2013, Legilasi Hukum Perkawinan di Indonesia, Pranada Media Grup, Jakarta.

Utomo, Laksanto. 2017. Hukum Adat. Depok: PT. Rajagrafindo Persada.

Wignjodipoero, Soerojo. 1983. Pengantar dan Asas-Asas Hukum Adat. Jakarta: PT Toko Gunung Agung.

Yunanto, Hukum Perkawinan Indonesia Kajian Kritis Atas Problematika, 2010 Undang-Undang Dasar 1945 
p-ISSN :2745-4088

e-ISSN :2798-6985

Undang Undang No. 1 Tahun 1974 Tentang Perkawinan

Undang-Undang No 16 tahun 2019 Tentang Perkawinan

Kitab Undang - undang Hukum Perdata

Peraturan pemerintah No. 9 tahun 1975 Tentang Pelaksanaan UU no 1 tahun 1974 